\title{
PENGARUH DEBT TO EQUITY RATIO, NET PROFIT MARGIN DAN TOTAL ASSET TURNOVER TERHADAP FINANCIAL DISTRESS PADA PERUSAHAAN DI BURSA EFEK JAKARTA
}

\author{
M. NURSIDIN, SE,M.Si \\ Universitas Dharmawangsa \\ muhammadnursidin@dharmawangsa.ac.id
}

\begin{abstract}
Abstrak
Penelitian ini bertujuan untuk mengetahui apakah debt to equity, net profit margin dan total assets turnover berpenngaruh positif terhadap financial distress pada perusahaan di Bursa Efek Jakarta. Jenis data yang digunakan dalam penelitian ini adalah data kuantitatif, yaitu data yang diperoleh dalam bentuk angka. Sumber data berupa data sekunder. Data sekunder dalam penelitian ini adalah berupa laporan keuangan tahunan selama periode 20162020. Populasi dalam penelitian ini adalah perusahaan subsektor farmasi yang terdaftar di Bursa Efek Indonesia periode 2016-20120 sebanyak 9 perusahaan. Sampel penelitian dalam penelitian ini sebanyak 35 perusahaan dengan teknik purposive sampling. Data dianalisis dengan menggunakan metode analisis regresi linear berganda. Hasil analisis memberikan persamaan Financial Distress = -0,445 + 1,477 Debt To Equity Ratio 3,820 Net Profit Margin + 117,564 Total Asset Turnover + e. Hasil analisis penelitian menunjukkan bahwa total asset turnover tidak berpengaruh signifikan terhadap financial distress berdasarkan hasil uji hipotesis secara parsial yaitu thitung $0,476<$ ttabel 2,03693 dan nilai signifikan $0,637>$ 0,05 , berarti H1 ditolak. Hasil analisis penelitian menunjukkan bahwa debt to equity ratio tidak berpengaruh signifikan terhadap financial distress berdasarkan hasil uji hipotesis secara parsial yaitu thitung $-0,956<$ ttabel 2,03693 dan nilai signifikan 0,346>0,05, berarti H2 ditolak. Hasil analisis penelitian menunjukkan bahwa net profit margin berpengaruh signifikan terhadap financial distress berdasarkan hasil uji hipotesis secara parsial yaitu thitung 5,546 > ttabel 2,03693 dan nilai signifikan $0,000<0,05$. Hasil penelitian ini didukung oleh nilai adjusted R Square sebesar $73 \%$ sedangkan sisanya sebesar $27 \%$ financial distress dijelaskan variabel lain yang tidak diteliti pada penelitian ini seperti current ratio, sales growth, earning per share.
\end{abstract}

Keyword : Debt To Equity Ratio, Net Profit Margin, Total Asset Turnover, Financial Distress

\section{PENDAHULUAN}

Financial Distress menunjukkan ketidakmampuan perusahaan dalam memenuhi kewajiban membayar hutang yang telah jatuh tempo pembayarannya. Informasi Financial Distress penting bagi perusahaan, karena dengan mengetahui kondisi Financial Distress suatu perusahaan sejak dini diharapkan manajemen perusahaan dapat mengambil tindakan-tindakan 
awal untuk mengantisipasi kondisi perusahaan yang mengarah pada kebangkrutan. Hal ini berdampak pada pengambilan keputusan ekonomis dari investor, karena sebelum memutuskan untuk berinvestasi, investor wajib memperhatikan kondisi kesehatan keuangan suatu perusahaan di laporan keuangan. Suatu perusahaan dapat dikategorikan sedang mengalami Financial Distress atau kesulitan keuangan apabila perusahaan tersebut menunjukkan angka negatif pada laba operasi, laba bersih dan nilai buku ekuitas serta perusahaan tersebut melakukan merger. Kinerja keuangan perusahaan semakin buruk, maka kemungkinan besar perusahaan akan menghadapi kebangkrutan. Namun, jika kinerja perusahaan membaik maka perusahaan memiliki kesempatan untuk mengatasi kesulitan keuangan (Financial Distress). Beberapa kinerja keuangan yang paling signifikan dalam memprediksi kesulitan keuangan (Financial Distress) suatu perusahaan adalah Debt To Equity Ratio, Net Profit Margin dan Total Asset Turnover.

\section{KAJIAN PUSTAKA}

Menurut Hery (2017:33) Financial Distress merupakan suatu kondisi di mana perusahaan sedang menghadapi masalah kesulitan keuangan. Kesulitan keuangan dimulai ketika perusahaan tidak dapat memenuhi jadwal pembayaran, atau ketika proyeksi arus kas mengindikasikan bahwa perusahaan tersebut akan segera tidak dapat memenuhi kewajibannya.

Menurut Rudianto (2013:251) Financial Distress atau kegagalan keuangan perusahaan dapat diartikan sebagai ketidakmampuan perusahaan untuk membayar kewajiban keuangannya pada saat jatuh tempo yang menyebabkan kebangkrutan atau kesulitan likuiditas yang mungkin sebagai awal kebangkrutan.

Menurut Murhadi (2013:61) Debt To Equity Ratio dapat juga menunjukkan perbandingan antara utang dan ekuitas perusahaan. Dengan kata lain bahwa semakin tinggi debt to equity ratio maka makin beresiko perusahaan.

Menurut Sudana (2015:26) Net Profit Margin merupakan rasio yang mengukur kemampuan perusahaan untuk menghasilkan laba bersih dari penjualan yang dilakukan perusahaan. Begitu juga menurut Murhadi (2013:64) Net Profit Margin mencerminkan kemampuan perusahaan dalam menghasilkan laba neto dari setiap penjualannya.

Menurut Harahap (2013:309) Total Asset Turnover merupakan rasio yang menunjukkan perputaran total aktiva diukur dari volume penjualan dengan kata lain seberapa jauh kemampuan semua aktiva menciptakan penjualan. Menurut Murhadi (2013:60) Total Asset Turnover menunjukkan efektivitas perusahaan dalam menggunakan asetnya untuk menciptakan pendapatan. 


\section{METODE PENELITIAN}

\section{Lokasi Penelitian}

Lokasi penelitian dilakukan di Bursa Efek Jakarta.

\section{Populasi dan Sampel}

Menurut Sujarweni (2015:80) populasi adalah keseluruhan jumlah yang terdiri atas objek atau subjek yang mempunyai karakteristik dan kualitas tertentu yang diterapkan oleh peneliti untuk diteliti dan kemudian ditarik kesimpulannya. Populasi dalam penelitian ini adalah perusahaan subsektor farmasi yang terdaftar di Bursa Efek Indonesia periode 20162020 sebanyak 9 perusahaan. Berdasarkan kriteria yang diambil tersebut, maka perusahaan yang menjadi sampel dalam penelitian ini sebanyak 35 yang terdiri dari 7 perusahaan subsektor farmasi yang terdaftar di Bursa Efek Indonesia selama 5 periode, yaitu periode 2016-2020

\section{Teknik Pengumpulan Data}

Teknik pengumpulan data yaitu dengan cara dokumentasi. Menurut Sanusi (2014:114) cara dokumentasi biasanya dilakukan untuk mengumpulkan data sekunder dari berbagai sumber, baik secara pribadi maupun kelembagaan. Data tersebut antara lain data laporan keuangan auditan masing-masing perusahaan manufaktur subsektor farmasi periode tahun 2013-2017 yang diperoleh melalui www.idx.co.id. Peneliti juga dapat menambahkan dan melakukan studi dokumentasi dengan cara pengkajian dan pendalaman literatur-literatur, seperti buku, jurnal dan laporan penelitian yang berkaitan dengan masalah yang diteliti.

\section{DISCUSSION}

\section{Pengaruh Debt To Equity Ratio Terhadap Financial Distress}

Hasil penelitian ini menunjukkan bahwa variabel Debt To Equity Ratio tidak berpengaruh signifikan terhadap Financial Distress pada sub sektor farmasi yang terdaftar di Bursa Efek Indonesia periode 2013-2017. Hal ini dapat dilihat dari hasil pengujian secara parsial (uji t) menunjukkan bahwa nilai thitung > ttabel yaitu dengan nilai $-0,956>2,03693$ dan nilai signifikan > 0,05 yaitu dengan nilai 0,346>0,05. Hasil pengujian ini menunjukkan bahwa hipotesis kedua (H2) ditolak. Menurut Rudianto (2013:194) Debt To Equity Ratio merupakan rasio yang menggambarkan seberapa besar modal pemilik dapat menutupi utang-utang kepada kreditor.

\section{Pengaruh Net Profit Margin Terhadap Financial Distress}

Hasil penelitian ini menunjukkan bahwa variabel Net Profit Margin berpengaruh signifikan terhadap Financial Distress pada sub sektor farmasi yang terdaftar di Bursa Efek Indonesia periode 2013-2017. Hal ini dapat dilihat dari hasil pengujian secara parsial (uji t) yang menunjukkan bahwa nilai thitung < ttabel yaitu dengan nilai 5,546 > 2,03693 dan nilai signifikan $<0,05$ yaitu dengan nilai $0,000<0,05$. Hasil pengujian menunjukkan bahwa hipotesis ketiga (H3) diterima. 


\section{Pengaruh Total Asset Turnover Terhadap Financial Distress}

Hasil penelitian ini menunjukkan bahwa Total Asset Turnover tidak berpengaruh dan tidak signifikan terhadap Financial Distress pada sub sektor farmasi yang terdaftar di Bursa Efek Indonesia periode 2013-2017. Hal ini dapat dilihat dari hasil pengujian secara parsial (uji t) yang menunjukkan bahwa nilai thitung < ttabel yaitu dengan nilai 0,476 2,03693 dan nilai signifikan >0,05 yaitu dengan nilai $0,637>0,05$. Hasil pengujian ini menunjukkan bahwa hipotesis pertama (H1) ditolak. Menurut Murhadi (2013:60) Total Asset Turnover menunjukkan efektivitas perusahaan dalam menggunakan asetnya untuk menciptakan pendapatan. Menurut Fahmi (2016:169) Financial Distress didefinisikan sebagai tahap penurunan kondisi keuangan yang terjadi sebelum terjadinya kebangkrutan atau likuiditasi. Total Asset Turnover yang rendah menunjukkan perusahaan terlalu banyak menempatkan dananya dalam bentuk asset. Sedangkan Total Asset Turnover yang tinggi menunjukkan perusahaan menggunakan sedikit asset atau asset yang digunakan sudah usang sehingga perusahaan dapat meningkatkan penjualan dan terhindar dari terjadinya Financial Distress.

\section{KESIMPULAN}

Berdasarkan hasil analisis dan pembahasan yang telah diuraikan pada bab-bab sebelumnya, maka kesimpulan dalam penelitian ini adalah :

1. Persamaan regresi linear berganda dalam penelitian ini adalah Financial

Distress = -0,445 + 1,477 Debt To Equity Ratio - 3,820 Net Profit Margin + 117,564

Total Asset Turnover + e. Hal ini memberikan arti bahwa variabel, Debt To Equity Ratio, Net Profit Margin dan Total Asset Turnover secara bersama-sama mempunyai pengaruh terhadap Financial Distress.

2. Secara parsial, variabel Debt To Equity Ratio tidak berpengaruh dan tidak signifikan terhadap Financial Distress pada sub sektor farmasi yang terdaftar di Bursa Efek Indonesia periode 2016-2020 dengan nilai thitung > ttabel yaitu $-0,956<2,03693$ dan nilai signifikan $>0,05$ yaitu 0,346>0,05. Dengan demikian hipotesis kedua ditolak

3. Secara parsial, variabel Net Profit Margin berpengaruh signifikan terhadap Financial Distress pada sub sektor farmasi yang terdaftar di Bursa Efek Indonesia periode 2016-2020 dengan nilai thitung $>$ tabel yaitu 5,546 2,03693 dan nilai signifikan $<0,05$ yaitu 0,000 < 0,05. Dengan demikian hipotesis ketiga diterima. 
4. Secara parsial, variabel Total Asset Turnover tidak berpengaruh dan tidak signifikan terhadap Financial Distress pada sub sektor farmasi yang terdaftar di Bursa Efek Indonesia periode 2016-2020 dengan nilai thitung < ttabel yaitu 0,476 < 2,03693 dan nilai signifikan $>0,05$ yaitu 0,637 > 0,05. Dengan demikian hipotesis pertama ditolak.

5. Secara simultan, variabel Total Asset Turnover, Debt To Equity Ratio dan Net Profit Margin berpengaruh signifikan terhadap Financial Distress pada sub sektor farmasi yang terdaftar di Bursa Efek Indonesia periode 2013-2017 dengan nilai Fhitung > Ftabel yaitu $31,681>2,91$ dan nilai signifikan $<0,05$ yaitu $0,000<0,05$. Dengan demikian hipotesis keempat diterima.

\section{Saran}

Berdasarkan hasil penelitian, penulis memberikan saran sebagai berikut :

1. Bagi penelitian selanjutnya, hendaknya dapat menambah atau mengganti variabel lain yang memiliki pengaruh secara signifikan terhadap Financial Distress, seperti Current Ratio, Sales Growth dan Earning Per Share. Selain itu peneliti selanjutnya diharapkan dapat menggunakan populasi lain selain perusahaan farmasi seperti perusahaan property \& real estate sehingga dapat mengetahui permasalahan yang terjadi dari hasil penelitian.

2. Bagi peneliti selanjutnya, diharapkan dapat menambah tambahan wasawan dan informasi mengenai rasio-rasio keuangan dalam memprediksi Financial Distress dan juga sebagai bahan referensi penelitian selanjutnya. 


\section{REFERENCES}

Ardian, Andre Vici. 2017. Pengaruh Rasio Likuiditas, Rasio Leverage, Rasio Aktifitas Dan Rasio Profitabilitas Terhadap Financial Distress (Pada Perusahaan Manufaktur Yang Terdaftar Di Bursa Efek Indonesia Periode Tahun 2013-2015). Jurnal Ilmiah Mahasiswa S1 Akuntansi Universitas Pandanaran. ISSN : 2502-7697.

Christananda, Claudia. 2017. Analisis Current Ratio Dan Net Profit Margin Untuk Memprediksi Kondisi Financial Distress Perusahaan (Studi pada Perusahaan Tekstil dan Garmen yang Terdaftar di Bursa Efek Indonesia Periode 20102015). e-Proceeding of Management. Vol.4, No.1 April 2017.

Darmadji, Tjiptono dan Hendry Fakhruddin. 2012. Pasar Modal Di Indonesia Edisi 3. PT. Salemba Empat. Jakarta.

Fahmi, Irham. 2016. Pengantar Manajemen Keuangan. Penerbit Alfabeta. Bandung.

Ghozali, Imam. 2016. Aplikasi Analisis Multivariate dengan Program SPSS 23. Badan Penerbit Universitas Diponegoro. Semarang.

Ginting, Mitha Christina. 2017. Pengaruh Current Ratio dan Debt to Equity Ratio (DER) Terhadap Financial Distress pada Perusahaan Property \& Real Estate di Bursa Efek Indonesia. Jurnal Manajemen. Vol 3. No. 2, p. 37 44.

Harahap, Sofyan Syafri. 2013. Analisis Kritis atas Laporan Keuangan. PT Raja Grafindo Persada. Jakarta.

Harmono. 2014. Manajemen Keuangan : Berbasis Balanced Scorecard. Penerbit Bumi Aksara. Jakarta.

Hery. 2016. Financial Ratio For Business. Penerbit PT Grasindo. Jakarta. 
